\title{
Penguatan Reformasi Birokrasi Menuju Era Society 5.0 di Indonesia
}

\section{Strengthening Bureaucratic Reform Towards Society 5.0 Era in Indonesia}

\author{
Andika Yasa ${ }^{1}$, Suswanta ${ }^{2}$, M. Rafi ${ }^{3}$, Fajar Rahmanto ${ }^{4}$, Deni Setiawan ${ }^{5}$, \\ Mochammad Iqbal Fadhlurrohman ${ }^{6}$ \\ 1,2,3,4,5,6 Magister Ilmu Pemerintahan, Universitas Muhammadiyah Yogyakarta, Indonesia \\ Email: andika.yasa2014@gmail.com ${ }^{1}$,soes_umy@yahoo.com²,rafy060611@gmail.com³ \\ ${ }^{4}$ fajarrahmantol@gmail.com ${ }^{4}$,deni.mip30@gmail.com5, fadlurrohmani84@gmail.com6
}

Diterima: 2 April 2021

Direvisi: 12 Juni 2021

Disetujui: 28 Juni 2021

DOI : 10.35967/njip.v20i1.139

\begin{abstract}
Abstrak: Memasuki era society 5.0, pemanfaatan teknologi sudah mulai mempertimbangkan aspekaspek humaniora terhadap proses penyelesaian masalah yang ada di sektor publik. Oleh karena itu, penelitian ini bertujuan untuk mengetahui penguatan reformasi birokrasi menuju era society 5.0 melalui tata kelola perencanaan pengembangan SDM Aparatur oleh KemenPANRB. Kemudian, Penelitian ini menggunakan metode penelitian kualitatif dengan pengumpulan data secara sekunder dari referensi terdahulu seperti buku, jurnal, serta dokumen publik yang berkaitan dengan fokus penelitian dan dianalisis menggunakan software NVivo12 Plus dengan pendekatan Cluster Analysis. Temuan studi ini menunjukkan bahwa Kementerian Pendayagunaan Aparatur Negara dan Reformasi Birokrasi (KemenPANRB) telah melakukan penguatan reformasi birokrasi melalui tata kelola perencanaan berbasis sistem merit di mana pada tahapan rekrutmen, pengangkatan, dan promosi, dilakukan pemeriksaan komparatif terhadap tingkat keahlian dan kompetensi masingmasing aparatur yang memenuhi persyaratan jabatan dengan tetap memperhatikan aspek integritas dan moralitas. Namun, penguatan reformasi birokrasi menuju era society 5.0 di Indonesia mengalami berbagai hambatan terkait masih dominannya patologi birokrasi, budaya korupsi, serta ketidaksiapan birokrasi akan pemanfaatan teknologi dan informasi dalam orientasi pelayanan publik kepada masyarakat. Oleh karena itu, Perencanaan pengembangan SDM Aparatur oleh KemenPANRB dalam memperkuat reformasi birokrasi menuju era Society 5.0 harus dilakukan secara tepat dengan merespons berbagai hambatan yang terjadi serta segala bentuk perubahan lingkungan dan perkembangan zaman.
\end{abstract}

Kata Kunci: Reformasi Birokrasi; Society 5.0

\begin{abstract}
Entering the era of society 5.0, the use of technology has begun to consider the humanities aspects of the problem-solving process in the public sector. Therefore, this study aims to determine the efforts to strengthen bureaucratic reform towards the era of society 5.0 through the governance of human resource development planning by the Ministry of State Apparatus Utilization and Bureaucratic Reform. Then, this study uses qualitative research methods with secondary data collection from previous references such as books, journals, and public documents related to the research focus and analyzed using NVivol2 Plus software with a Cluster Analysis approach. The findings of this study indicate that the Ministry of State Apparatus Utilization and Bureaucratic Reform has strengthened bureaucratic reform through a merit system-based planning governance, where at the stages of recruitment, appointment, and promotion, an examination is carried out on the level of expertise and competence of each apparatus that meets the job requirements while taking into account the aspects of integrity and morality. However, strengthening bureaucratic reform towards the era of society 5.0 in Indonesia has encountered various obstacles related to the still-dominant bureaucratic pathology, a culture of corruption, and the unpreparedness of the bureaucracy for the use of technology and information in the orientation of public services to the community. Therefore, the planning for human resource development by Ministry of State Apparatus Utilization and Bureaucratic Reform in strengthening bureaucratic reform towards the Society 5.0 era must be carried out appropriately by responding to various obstacles that occur as well as all forms of environmental change and development of the times.
\end{abstract}

Keywords: Bureaucratic Reform; Society 5.0 


\section{Pendahuluan}

Memasuki era society 5.0, implementasi penggunaan teknologi sudah mulai memperhatikan aspek-aspek humaniora guna menciptakan berbagai tools pada proses pemecahan masalah-masalah sosial yang ada (Faruqi, 2019). Tentunya hal ini memerlukan pengelolaan sumber daya manusia (SDM) yang optimal guna mendongkrak kredibilitas organisasi dengan meningkatkan efisiensi masing-masing aparatur birokrasi di bidang informasi, komunikasi, dan teknologi (TIK), dengan tujuan mempermudah pelaksanaan tugas-tugas di masa depan (Rustandi, 2019). Kemudian, Sebagai bagian dari upaya untuk mewujudkan good governance, maka SDM aparatur birokrasi haruslah selalu berorientasi pada pemanfaatan teknologi dalam penyelenggaraan layanan pemerintah, penyederhanaan berbagai regulasi dan juga dalam proses reformasi birokrasi (Mardawani \& Relita, 2019). Pada dasarnya, upaya perbaikan struktural penyelenggaraan pemerintahan di bidang kelembagaan, manajemen, dan sumber daya manusia dikenal dengan reformasi birokrasi (Adlin \& Handoko, 2019; Ferizaldi, 2018). Di mana hadirnya keinginan dalam reformasi birokrasi dapat dipahami sebagai suatu proses untuk menyegerakan perubahan menjadi lebih baik dengan tujuan untuk mewujudkan birokrasi penyelenggaraan pemerintahan yang bersih, terbuka, dan akuntabel (Ferizaldi, 2019; Haning, 2018).

Penguatan kapasitas SDM Aparatur sangat diperlukan oleh organisasi pemerintah baik di pusat maupun daerah sebagai upaya adaptasi terhadap era perkembangan yang terjadi (Parjaman et al., 2019). Tata kelola SDM juga memiliki peran strategis untuk mendukung kesuksesan dalam reformasi birokrasi Indonesia, di mana tahap awal dalam tata kelola SDM di sektor pemerintahan memiliki kesamaan dengan sektor privat yakni melakukan perencanaan SDM yang tepat dan akurat guna mencapai tujuan organisasi (Zaenuri, 2015). Kemudian, Perencanaan sumber daya manusia merupakan landasan untuk menyusun rencana kerja organisasi di divisi kerja sumber daya manusia. Suatu proses yang menjadi bagian penting dalam perencanaan SDM adalah merencanakan pengembangan dengan berkonsentrasi pada pendidikan dan pelatihan, transisi dan promosi, serta mengisi kekosongan jabatan yang membutuhkan tenaga ahli yang berpengalaman (Dzakiyati, 2018; Sudrajat, 2014). Dengan melaksanakan pengembangan SDM maka secara tidak langsung suatu organisasi telah melakukan adaptasi atas perubahan lingkungan dan perkembangan era untuk membangun SDM yang lebih berkualitas, karena dengan hal tersebut maka kinerja organisasi akan semakin meningkat (Sirih et al., 2019). Selain itu, Pengembangan SDM Aparatur menjadi penting untuk dilakukan karena akan memudahkan lembaga pemerintah baik kecil maupun besar untuk mencapai tujuan mereka yang terkait dengan jumlah pekerja dengan keterampilan yang diperlukan untuk membantu proses organisasi dalam pencapaian tujuan dan sasaran yang diinginkan. Pada intinya, Membangun SDM Aparatur mencakup pengembangan kompetensi diri yang unggul di dalam diri aparatur SDM itu sendiri sesuai dengan tugas dan kegiatan yang dilakukan serta bertujuan untuk mengembangkan aspek kecerdasan unggul, kemampuan unggul, dan sikap mental yang unggul (Annisah, 2017; Zaenuri, 2015).

SDM di berbagai jenis institusi publik perlu meningkatkan kompetensi diri dalam manajemen e-resources, manajerial leadership, literasi digital dan research serta melakukan transformasi sebagai persiapan menghadapi perubahan yang semakin cepat dalam mewujudkan masyarakat berpengetahuan (Nashihuddin \& Suryono, 2018). Untuk membangun birokrasi yang cepat dan gesit dalam menyediakan layanan publik diperlukan pembenahan secara struktural (Faedlulloh et al., 2020). Kemudian, Keberlanjutan akan reformasi birokrasi harus tetap dijalankan untuk meningkatkan kualitas pelayanan publik sehingga menyebabkan adanya rasa kepercayaan dari masyarakat terhadap penyelenggaraan pelayanan dari aparatur pemerintah (Purwaningsih et al., 2019). Sehingga, Reformasi birokrasi terkait erat dengan aspek reformasi lainnya seperti pergeseran pola pikir, pengembangan struktur layanan publik berbasis teknologi, serta penyempurnaan regulasi dan kepemimpinan (Hartanto, 2019). 
Sistem pemerintahan berbasis elektronik dengan pendekatan bottom-up dapat menjadi alternatif dalam proses pengelolaan yang efektif, efisien, dan transparan (Yuhefizar et al., 2019). Oleh karena itu adanya inovasi diperlukan untuk adaptasi terhadap perubahan dan pengembangan SDM aparatur pemerintah secara berkelanjutan agar dapat menciptakan inovasi pelayanan publik yang berorientasi terhadap pemanfaatan teknologi informasi (Wardani, 2019). Keinginan publik akan birokrasi yang transparan dan akuntabel, ditambah dengan kondisi lingkungan yang semakin tidak menentu, mendorong pemerintah untuk bereksperimen dengan tata kelola sebagai bagian dari upayanya untuk mereformasi administrasi sektor publik (Kurniati \& Nugroho, 2019). Sehingga revitalisasi birokrasi dalam melakukan transformasi birokrasi yang berorientasi ke arah e-governance dilakukan dengan mengembangkan inovasi, membangun kolaborasi dan sinergi serta memberikan respons atas terjadinya perubahan lingkungan yang sangat cepat (Rahadian, 2019). Selain itu, orientasi pelayanan publik kepada masyarakat tidak hanya berperan untuk peningkatan kinerja birokrasi, akan tetapi juga menjadi unsur strategis dalam mengembangkan pelayanan birokrasi pemerintah di masa depan (Hidayat, 2019). Oleh karena itu, Dalam rangka meningkatkan pembangunan yang berkelanjutan, Aparatur pemerintah harus mampu meningkatkan kompetensi dirinya dalam bidang pengetahuan dan teknologi serta harus memiliki kreativitas untuk mengantisipasi berbagai persoalan baik formal maupun informal (Sakti, 2019), melalui pemanfaatan teknologi kecerdasan yang sudah banyak dilakukan pada sektor publik, untuk memaksimalkan produktivitas hasil kerja yang dilaksanakannya (Yudoprakoso, 2019). Dengan demikian, Penerapan teknologi kecerdasan buatan akan dapat memberikan manfaat untuk membantu memperoleh informasi melalui pengumpulan data yang dapat dijadikan landasan untuk pengambilan keputusan dan perbaikan sistem otomatisasi di masa depan (Saluky, 2018).

Dalam era disrupsi teknologi sampai munculnya revolusi industri 4.0, aparatur pemerintah memainkan peran vital dalam administrasi pemerintahan (Nasution et al., 2019), di mana dalam revolusi industri 4.0 dibutuhkan komitmen dan kesadaran diri untuk membangun budaya birokrasi demi menjaga kepercayaan masyarakat (Rivai, 2019). Untuk membangun sumber daya manusia yang berdaya saing tinggi, diperlukan peningkatan keterampilan, pendidikan dan pelatihan, serta peningkatan budaya kerja (Sihite, 2018). Secara historis, pada era revolusi industri 4.0, berbagai jenis teknologi mengantarkan perubahan budaya kerja manusia menuju era digitalisasi dan otomatisasi (Suwardana, 2018). Kemudian, karena adanya komponen pelengkap yang berbeda, baik era revolusi industri 4.0 maupun era society 5.0 akan dapat mempengaruhi semua aktivitas manusia. Untuk mencapai tujuan era society 5.0 diawali dengan menciptakan "human-centric society" yang mendorong pembangunan ekonomi masyarakat serta memberikan solusi dalam meningkatkan kualitas hidup masyarakat (Wasitarini, 2019). Ketika di era industri 4.0, semua informasi yang terkumpul melalui jaringan akan dianalisis langsung oleh manusia, memasuki era society 5.0 sebagian besar jumlah informasi dari sensor pada ruang fisik akan diakumulasi menjadi satu dalam cyberspace yang akan dianalisis menggunakan artificial intelligence di mana nantinya hasil analisis tersebut melalui feedback akan diberikan kembali ke manusia yang berada di ruang fisik dalam berbagai macam bentuk yang dihasilkan (Arief \& Saputra, 2019). Oleh karena itu, untuk mendorong tata kelola yang cerdas, kualitas konten harus ditingkatkan, seiring dengan kecepatan publikasi, dengan tetap memperhatikan keakuratan data dan informasi (Maizunati, 2018).

Jika di telusuri kembali, pada dasarnya berbagai tahapan konsep society bermula dari society 1.0 yang didefinisikan sebagai sekelompok orang yang berburu dan berkumpul dalam keharmonian dengan alam. Kemudian, society 2.0 merupakan konsep suatu kelompok budidaya pertanian, kemajuan organisasi, dan pembangunan negara. Selanjutnya, Society 3.0 adalah konsep masyarakat yang mampu mendorong industrialisasi dan memfasilitasi produksi massal melalui revolusi industri. Sedangkan, konsep Society 4.0 akan mengidentifikasi masyarakat informasi yang mewujudkan nilai tambah yang lebih besar dengan menghubungkan aset tidak 
berwujud melalui jaringan informasi. Kemudian, era society 5.0 saat ini merupakan suatu terobosan konsep masyarakat informasi yang dibangun di atas society 4.0 dan bertujuan untuk mewujudkan masyarakat yang berpusat pada manusia yang sejahtera di mana setiap orang akan menikmati hidup secara maksimal (Fukuyama, 2018; Harayama, 2016).

Pada intinya, era society 5.0 memiliki tujuan utama yakni untuk menciptakan kesejahteraan melalui pertumbuhan ekonomi dan perkembangan teknologi kepada seluruh lapisan masyarakat (Wasitarini, 2019). Era society 5.0 mengacu pada konsep yang menerapkan teknologi pada revolusi industri 4.0 yang memperhatikan aspek humaniora untuk melahirkan cara-cara penyelesaian masalah-masalah sosial (Faruqi, 2019). Kemudian, era society 5.0 adalah suatu bentuk kecerdasan sosial yang secara kuat dapat mengintegrasi antara ruang fisik dan ruang cyber (Salgues, 2018). Dengan demikian, era society 5.0 dapat dipahami sebagai salah satu bentuk kehidupan masyarakat yang menggabungkan data melalui teknologi informasi untuk mendorong peningkatan kecerdasan sumber daya manusia dalam pengembangan berbagai peluang yang dapat dilaksanakan berdasarkan aspek humaniora guna menyelesaikan berbagai persoalan sosial.

Dalam konteks birokrasi di Indonesia, saat ini terlihat dengan jelas bahwa orientasi pelayanan publik masih belum berjalan maksimal karena berbagai faktor yang perlu dibenahi, serta menjadi catatan penting bagi pemerintah untuk terus meningkatkan efisiensi sektor publiknya (Wicaksono et al., 2019; Islah, 2018). Pertama, Masalah korupsi di birokrasi telah menjadi bagian dari feodalisme yang masih terpelihara dalam sistem birokrasi, karena berbagai keputusan publik yang diambil melalui birokrasi pemerintahan tidak pernah lepas dari pola topdown (Hasan, 2012). Kedua, Banyaknya penyuapan yang melibatkan pejabat politik dan pejabat birokrasi menjadi ancaman nyata terhadap nilai budaya luhur bangsa karena bertentangan dengan tujuan negara dalam mewujudkan kesejahteraan bagi seluruh masyarakat (Azhary, 2019). Ketiga, masih dominannya patologi birokrasi yang berbelit-belit dalam pelayanan publik dan belum mampu diminimalisir secara optimal. Sehingga, pemahaman secara holistik dan komprehensif oleh aparatur birokrasi terhadap pola hubungan korupsi yang sering terjadi diyakini menjadi penting agar dapat meminimalisasir terjadinya tindak korupsi di sektor pelayanan publik (Hadi, 2016). Selain itu, ketidakmampuan birokrasi dalam mendukung terciptanya era society 5.0 juga merupakan dinamika yang begitu kompleks di Indonesia (Kumorotomo, 2019; Sugiono, 2020). Hal ini dikarenakan di era Society 5.0 birokrasi di Indonesia harus mampu memahami berbagai pemanfaatan big data sebagai sumber informasi yang didukung oleh teknologi dan kesiapan para aktor dalam proses pembuatan kebijakan serta juga harus memperhatikan aspek-aspek kemanusiaan lainnya bagi masyarakat (Rahmanto et al., 2021).

Banyak kajian sebelumnya telah melakukan berbagai studi tentang perubahan birokrasi dalam tata kelola sumber daya manusia (SDM) pemerintah. Di mana penelitian (Umam, 2019) menemukan bahwa kepemimpinan transformatif sebagai upaya dalam mengubah birokrasi dipercaya mampu meningkatkan kinerja birokrasi menghadapi tantangan pembaruan dan tuntutan perubahan era. Hal tersebut juga didukung oleh temuan (Parjaman et al., 2019) yang menjelaskan bahwa kepemimpinan dalam birokrasi memiliki peran penting dalam penguatan kapasitas SDM Aparatur, sebagai motivator dan inspirator untuk membawa perubahan dan adaptasi organisasi pada perkembangan zaman serta menuju ke arah yang lebih baik. Kemudian, Dalam tata kelola reformasi birokrasi menurut (Setiawan \& Fauzi, 2019) dikatakan bahwa peran etika politik adalah sebagai alat kontrol dan pengawasan yang sangat efektif untuk mendukung keberhasilan reformasi birokrasi. Kemudian penelitian dari (Soekarsono, 2019) yang menyatakan bahwa memasuki era disrupsi, Pemerintah perlu mengubah mental birokrasi menjadi bermental korporasi. Berikutnya, Penelitian dari (Henriyani, 2019) memaparkan bahwa kebudayaan akan berdampak kuat pada perbaikan hasil reformasi, karena berkaitan dengan kepercayaan pada prinsip dan sikap yang dibentuk dan diekspresikan dalam birokrasi itu sendiri. 
Penelitian ini menjadi penting karena berbagai dinamika yang kompleks telah terjadi dalam tata kelola perencanaan pengembangan SDM aparatur birokrasi di era society 5.0 yang semakin pesat karena harus menyelaraskan antara kapabilitas birokrasi yang siap akan kemajuan teknologi dan juga mampu memperhatikan aspek perubahan kehidupan masyarakat secara berkelanjutan (Alekseev-apraksin \& Bertova, 2021; Fujii et al., 2018; Roblek et al., 2020). Dengan demikian, perlu diketahui bagaimana upaya yang dapat dilakukan untuk merealisasikan penguatan reformasi birokrasi menuju era society 5.0 di Indonesia. Oleh karena itu, Penelitian ini bertujuan untuk menjelaskan berbagai upaya penguatan reformasi birokrasi menuju era society 5.0 melalui tata kelola perencanaan pengembangan SDM Aparatur oleh Kementerian Pendayagunaan Aparatur Negara dan Reformasi Birokrasi (KemenPANRB). Kemudian, Alasan penting dilakukannya penelitian ini adalah untuk dapat memahami lebih jauh terkait peranan KemenPANRB dalam menata, mengelola dan mengembangkan kemampuan setiap aparatur negara. Selain itu, Melalui KemenPANRB, perencanaan pengembangan SDM Aparatur melalui pengembangan kompetensi dan keterampilan dalam pemanfaatan teknologi juga harus tetap mengedepankan karakter humanisme dalam setiap melayani masyarakat maupun menyelesaikan persoalan publik lainnya. Dengan demikian, hal tersebut menarik untuk dianalisis lebih mendalam agar tata kelola perencanaan pengembangan SDM Aparatur dapat berdampak terhadap keberhasilan reformasi birokrasi di organisasi pemerintah dalam merespons segala bentuk perubahan lingkungan dan perkembangan zaman. Hal ini sebagaimana disajikan pada Gambar 1.

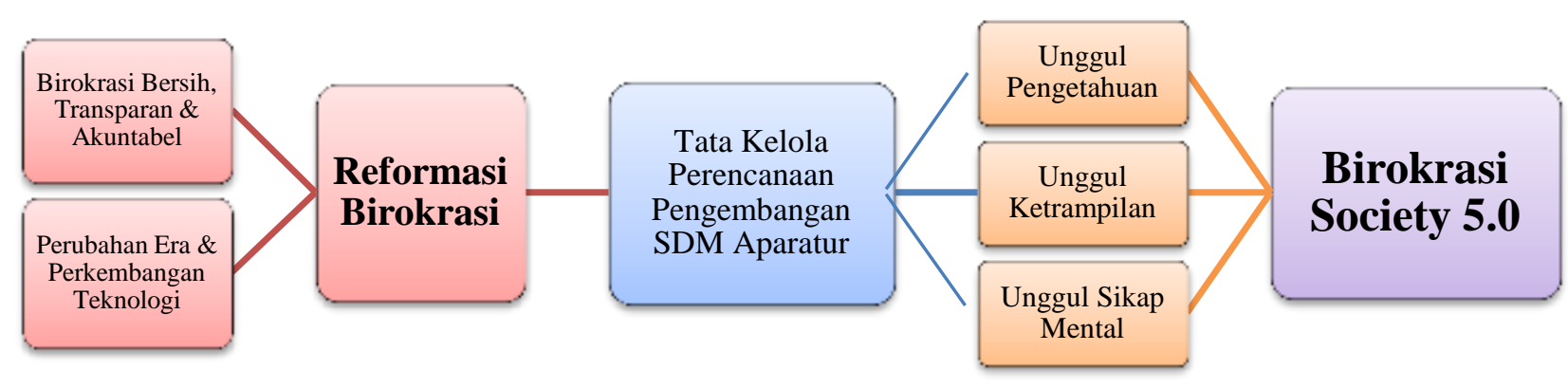

Gambar 1. Kerangka Teoretis

\section{Metode Penelitian}

Penelitian ini menggunakan metode penelitian kualitatif (Aspers \& Corte, 2019), yang bertujuan untuk mengetahui terkait bagaimana tata kelola perencanaan pengembangan SDM Aparatur dalam memperkuat reformasi birokrasi untuk merespons terjadinya segala perubahan lingkungan dan perkembangan masyarakat menuju era society 5.0 oleh KemenPANRB. Oleh karena itu, Penelitian ini akan memberikan penjelasan mengenai tata kelola perencanaan pengembangan SDM Aparatur untuk memperkuat reformasi birokrasi menghadapi perubahan era menuju era society 5.0 di mana pemanfaatan teknologi untuk meningkatkan kinerja SDM akan tetap mempertimbangkan aspek humanisme dalam setiap penyelesaian masalah sosial. Kemudian, Data dalam penelitian ini dikumpulkan dengan menggunakan teknik literature review yaitu metode pengumpulan informasi penelitian dari berbagai buku dan jurnal yang relevan dengan fokus studi (Farida, 2019). Selanjutnya, teknik analisis data dalam penelitian ini menggunakan aplikasi Nvivo 12 Plus yang merupakan suatu aplikasi penelitian kualitatif yang mampu melakukan analisis data secara efektif dan efisien serta mampu menampilkan data ke dalam bentuk tabel, grafik maupun diagram (Bandur, 2019). Berikutnya, dilakukan penarikan kesimpulan yang merupakan hasil akhir dari analisis data dengan melakukan interpretasi melalui refleksi terhadap data penelitian (Gumilang, 2016). 


\section{Hasil dan Pembahasan}

Seiring dengan laju perkembangan teknologi dan penciptaan inovasi, pada prosesnya tata kelola pemerintahan yang baik di Indonesia belum dapat diadopsi dalam kehidupan masyarakat sehari-hari karena tidak ada platform yang disiapkan dalam menuju era society 5.0 (Sugiono, 2020). Penelitian (Saksono \& Manoby, 2021), menjelaskan bahwa tata kelola pemerintahan di Indonesia belum dapat berjalan secara optimal untuk mendorong terwujudnya era society 5.0. Selain itu, penelitian ini juga memberikan beberapa rekomendasi yaitu peningkatan infrastruktur internet yang menjangkau wilayah pelosok, penyiapan legal framework, kerja sama lembaga negara dan korporasi, dan penguatan kebijakan inovatif berbasis riset yang mendukung terciptanya birokrasi menuju era society 5.0 di Indonesia. Secara global, konsep society dapat dilihat pada Gambar 2.

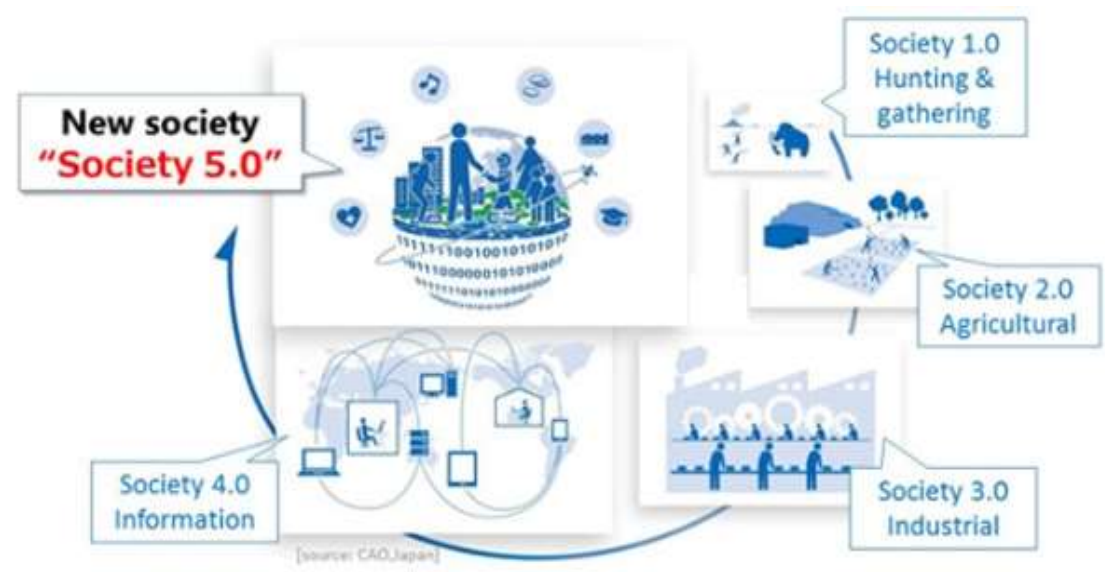

Gambar 2. Perubahan Konsep Society

(Sumber: Faruqi, 2019).

Gambar 2 menunjukkan bahwa secara global konsep society dimulai dari era society 1.0 ketika masyarakat berburu dan mencari bahan makanan serta pola kehidupan yang sangat erat dengan kehidupan alam sekitar. Sedangkan di era society 2.0 pola kehidupan masyarakat cenderung pada konsep budidaya pertanian. Selanjutnya, di era Society 3.0 konsep kehidupan masyarakat berevolusi pada konsep industrialisasi. Kemudian, di era Society 4.0 konsep kehidupan masyarakat didominasi pada pola sistem informasi. Berikutnya, menuju era Society 5.0, setiap negara didunia diharapkan mampu mengadopsi suatu konsep kehidupan masyarakat dalam era teknologi dan informasi yang ditandai dengan perkembangan Artificial Intelligence, Robotics, Automation, Big Data, dan Internet of Things (Faruqi, 2019; Fukuyama, 2018).

Dengan demikian, Perubahan era dengan disertai perkembangan teknologi yang semakin cepat telah menghadirkan konsekuensi besar bagi setiap organisasi termasuk organisasi di sektor pemerintahan (Saksono \& Manoby, 2021). Dalam merespons perubahan tersebut untuk mewujudkan dimensi pembangunan nasional yang meliputi pembangunan SDM, pembangunan sektor unggulan serta pembangunan kewilayahan dapat dilakukan melalui tata kelola SDM Aparatur dan reformasi birokrasi. Birokrasi pemerintahan telah berkembang menjadi senjata esensial dalam masyarakat modern, di mana keberlanjutan reformasi birokrasi merupakan konsekuensi logis dari tujuan utama negara untuk mencapai kesejahteraan rakyat (Fajriah \& Razak, 2020). Implementasi reformasi birokrasi SDM Aparatur mempunyai peran strategis dan penting sebagai bagian dalam mendukung kelancaran pembangunan nasional, sehingga tanpa adanya reformasi birokrasi yang baik maka setiap target yang telah ditetapkan untuk mencapai pembangunan nasional akan sulit tercapai. Oleh karenanya dalam reformasi birokrasi penting untuk terus melakukan perbaikan-perbaikan melalui berbagai macam regulasi, modernisasi kebijakan tata kelola SDM Aparatur di tingkat pusat dan daerah dengan menyesuaikan tugas 
fungsi organisasi pemerintah atas terjadinya perubahan era yang cepat. Sebagai upaya dalam mewujudkan good governance dapat dilakukan melalui peningkatan SDM Aparatur, dan melakukan integrasi pemanfaatan teknologi untuk penyelenggaraan layanan pemerintah, penyederhanaan berbagai regulasi dan reformasi birokrasi (Mardawani \& Relita, 2019). Hal ini sebagaimana disajikan pada Gambar 3.

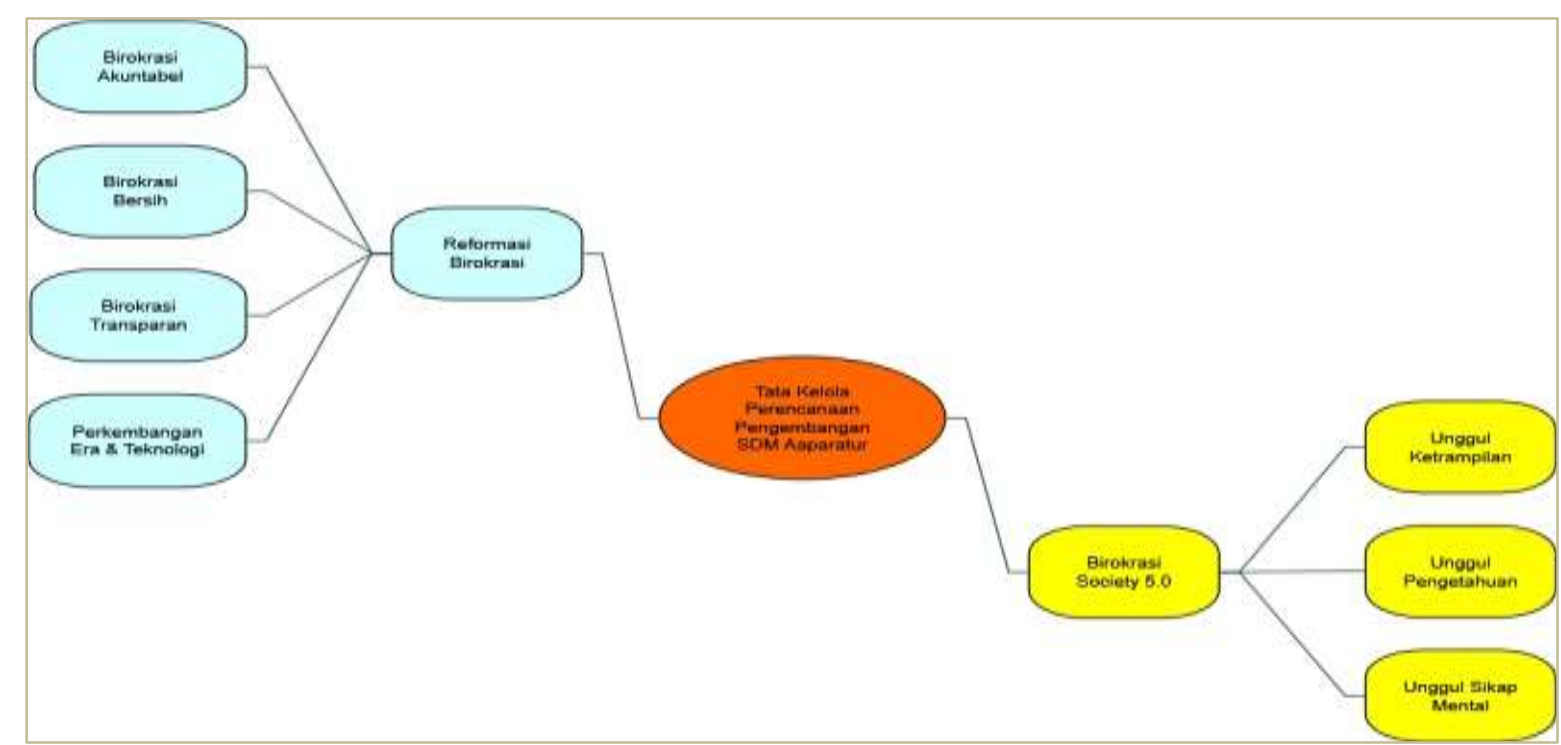

Gambar 3. Reformasi Birokrasi Menuju Era Society 5.0

(Sumber: Hasil Mind Mapping NVivo12 Plus, 2021).

Dari Gambar 3 di atas terlihat bahwa adanya reformasi birokrasi dilakukan untuk menciptakan birokrasi yang akuntabel, bersih dan juga transparan serta adanya tuntutan untuk menyesuaikan terhadap perkembangan era dan teknologi. Birokrasi yang akuntabel dilaksanakan dengan harapan setiap kegiatan dan output yang dilakukan oleh aparatur birokrasi dapat dipertanggungjawabkan dengan baik dan benar kepada publik sesuai dengan ketentuan peraturan perundang-undangan yang berlaku. Kemudian, birokrasi yang bersih diharapkan akan menjadikan setiap pegawai pemerintah memiliki integritas tinggi serta bebas dari segala bentuk kepentingan politik dan tindakan korupsi. Selanjutnya, birokrasi yang transparan diharapkan akan menjadikan tata kelola SDM Aparatur pemerintah bersifat terbuka untuk publik mulai dari penyelenggaraan sistem rekrutmen, penempatan pegawai, sistem promosi dan mutasi jabatan sampai pengembangan kompetensi pegawai yang sesuai dengan kebutuhan serta tuntutan tugas dan fungsi organisasi pemerintah.

Reformasi birokrasi SDM Aparatur yang dilakukan harus mampu menyesuaikan dengan setiap dimensi perubahan penyelenggaraan pemerintahan untuk mewujudkan pembangunan nasional. Reformasi birokrasi SDM Aparatur menjadi prasyarat dasar untuk menciptakan kualitas SDM pemerintahan yang unggul, lebih profesional, berkinerja tinggi, bersih dan akuntabel sehingga mampu menghadapi segala bentuk perubahan perkembangan global dimasa mendatang. SDM Aparatur yang mampu melaksanakan tugas-tugas penyelenggaraan pemerintahan, konstruksi, dan pelayanan publik sangat dibutuhkan guna mengikuti perkembangan zaman dan teknologi, serta kondisi yang semakin kompetitif di segala aspek kehidupan sosial. Melalui SDM Aparatur yang semakin berkualitas maka dapat memberikan kontribusi optimal kepada publik serta menjadikan organisasi pemerintah yang unggul dalam menyesuaikan terhadap perubahan global dan tuntutan dari publik. Sehingga tata kelola sumber daya manusia diperlukan untuk meningkatkan kredibilitas organisasi pemerintah melalui pengembangan SDM Aparatur dengan berorientasi kompetensi terhadap ICT yang berperan penting mendukung pelaksanaan tugas dimasa depan (Rustandi, 2019). 
Melalui tata kelola perencanaan pengembangan SDM Aparatur yang terstruktur dengan baik, maka dimasa depan akan dapat menciptakan birokrasi era society 5.0 yang merupakan suatu konsep birokrasi pemerintah dengan kualitas SDM Aparatur yang unggul pengetahuan, unggul ketrampilan dan unggul sikap dan mental. Menyesuaikan dengan perubahan dan perkembangan era maka sudah menjadi kewajiban bagi aparatur pemerintah memiliki keunggulan dalam pengetahuan yang berarti mampu mengetahui perkembangan informasi pengetahuan baik dari tingkat lokal, nasional maupun internasional. Kemudian unggul dalam keterampilan artinya dengan kompetensi yang dimiliki mampu memanfaatkan segala bentuk sarana prasarana teknologi untuk mendukung kelancaran tugas dan fungsi pekerjaan yang ada. Unggul dalam sikap mental artinya setiap pegawai pemerintah dalam menjalankan tugas dan fungsinya yang didukung dengan pemanfaatan teknologi tetap memperhatikan sisi humanisme ketika memberikan pelayanan kepada masyarakat dalam rangka pengambilan peran sebagai problem solving untuk segala bentuk permasalahan sosial yang terjadi akibat perubahan era yang menyebabkan timbulnya kompleksitas permasalahan di sektor publik. Sehingga birokrasi society 5.0 yang merupakan birokrasi masa depan sangat membutuhkan pengembangan ilmu pengetahuan yang didukung oleh pemanfaatan teknologi dan SDM Aparatur pemerintah yang berkompeten secara bersama-sama untuk dapat berkontribusi secara optimal terhadap berbagai sektor kehidupan sosial masyarakat (Faruqi, 2019).

Pengelolaan pemerintahan dan sumber daya manusia yang efektif dengan didukung oleh sistem pengawasan dan transparansi akan mendorong potensi perbaikan pola pikir dan budaya masing-masing birokrat menuju budaya yang lebih kompeten, efisien, dan akuntabel. Selain itu, Penerapan reformasi birokrasi sumber daya manusia diharapkan dapat menurunkan angka korupsi dan meningkatkan efektivitas pengelolaan kebijakan dan layanan publik, serta efisiensi pegawai. Sehingga hasil pembangunan nasional secara nyata akan dirasakan seluruh lapisan masyarakat. Kemudian, Upaya menciptakan birokrasi society 5.0 pada akhirnya akan meningkatkan kepercayaan publik terhadap pemerintah. Situasi dalam proses tersebut akan berdampak pada gambaran ideal dari birokrasi, yaitu kemampuan beradaptasi dengan perkembangan zaman dan teknologi, serta menjadi birokrasi yang peka terhadap berbagai jenis tuntutan masyarakat. Semakin tingginya ekspektasi publik terhadap kinerja birokrasi merupakan salah satu dampak semakin majunya perkembangan era sehingga aparatur birokrasi harus mampu membangun budaya birokrasi yang responsif serta aspiratif dalam memenuhi keinginan publik (Rivai, 2019).

Adanya tuntutan dari masyarakat dan tuntutan perkembangan era baik di tingkat nasional maupun global terhadap kualitas kompetensi dari SDM Aparatur pemerintah yang profesional dalam melaksanakan tugas dan fungsi pemerintahan, pembangunan serta pelayanan masyarakat menjadikan urgensi reformasi birokrasi SDM Aparatur sebagai suatu hal yang tidak bisa ditunda lagi. Oleh karena itu, perlu dibangun suatu tata kelola perencanaan pengembangan SDM Aparatur pemerintah yang baik untuk mendukung ketersediaan sumber daya manusia yang memiliki profesionalitas, berkinerja tinggi serta unggul dalam bidang pengetahuan, keterampilan dan sikap mental pada masa mendatang. Berdasarkan pada kondisi tersebut maka sudah seharusnya SDM di berbagai jenis institusi publik perlu meningkatkan kompetensi diri dalam manajemen e-resources, manajerial leadership, literasi digital serta melakukan transformasi kepemimpinan sebagai upaya dalam mengubah birokrasi untuk menghadapi tantangan pembaruan dan tuntutan perubahan era (Nashihuddin \& Suryono, 2018; Umam, 2019). 


\section{Tata Kelola SDM Aparatur Menuju Birokrasi Era Society 5.0}

Sebagai instrumen penting dalam tata kelola SDM Aparatur, maka salah satu upaya yang dilakukan oleh KemenPANRB untuk memperkuat reformasi birokrasi adalah melalui perencanaan pengembangan sumber daya manusia. Dalam orientasinya, pelaksanaan perencanaan pengembangan SDM Aparatur bertujuan untuk menghasilkan PNS yang berkualitas, memiliki nilai-nilai fundamental, kompetensi profesional, bebas intervensi politik, dan tidak terlibat dalam praktik kolusi maupun nepotis. Aparatur pemerintah sebagai suatu disiplin ilmu diharapkan dapat mengelola dan meningkatkan diri, serta mempertanggungjawabkan keberhasilannya melalui penggunaan kerangka kerja sistem merit (berbasis kompetensi) dalam pelaksanaan pengelolaan SDM bagi aparatur pemerintah. Dengan demikian, Kompetensi memainkan peran penting dalam menumbuhkan produktivitas SDM di periode kemajuan teknologi yang memungkinkannya untuk berperan dalam mencapai tujuan organisasi (Sihite, 2018). Untuk mendukung keberhasilan aparatur dalam penyelenggaraan tugas dan fungsi pemerintah maka setiap pegawai harus memiliki profesionalitas kerja yang diperkuat dengan pelaksanaan rencana pengembangan SDM Aparatur berbasis sistem merit.

KemenPANRB telah mengatur penciptaan SDM Aparatur melalui sistem merit yang membandingkan keahlian, kinerja, dan kompetensi yang dibutuhkan suatu peran dengan tingkat kompetensi dan kinerja yang dimiliki pelamar pada tahap rekrutmen, pengangkatan, dan promosi jabatan yang digabungkan secara transparan dan kompetitif. Lebih lanjut, pemilihan karier PNS difokuskan pada keterampilan, kompetensi, penilaian kinerja, dan kebutuhan departemen di pemerintahan, dengan tetap memperhatikan masalah integritas dan moralitas. Kejujuran dan kepatuhan terhadap regulasi, kesediaan untuk berkolaborasi, dan pemberian layanan yang optimal kepada masyarakat adalah ukuran dari aspek integritas. Sedangkan penerapan dan pengamalan prinsip-prinsip agama, budaya, dan sosial digunakan untuk menentukan aspek moralitas. Sasaran utama dari KemenPANRB untuk meningkatkan kompetensi SDM Aparatur meliputi kompetisi teknis, kompetensi manajerial, dan kompetensi sosial kultural. Spesialisasi pendidikan, persiapan profesional praktis, dan pengalaman kerja teknis semuanya dapat digunakan untuk menilai kompetensi teknis. Tingkat pendidikan, pelatihan manajemen, dan pengalaman kepemimpinan akan digunakan untuk menilai kompetensi manajerial. Pengalaman kerja dalam masyarakat majemuk baik dari segi agama, suku, dan budaya akan digunakan untuk menentukan kompetensi sosial kultural agar memberikan perspektif kebangsaan. Selain itu, peningkatan kompetensi juga akan dilaksanakan melalui kesempatan bekerja di instansi lain di area pusat dan lokal serta melalui pertukaran pegawai negeri dan swasta dengan maksimal waktu satu tahun dalam koordinasi Lembaga Administrasi Negara (LAN) dan Badan Kepegawaian Negara (BKN). Alhasil, berbagai inisiatif KemenPANRB merupakan implementasi dalam memperkuat reformasi birokrasi dengan produktivitas tinggi dalam menghadapi persaingan dalam periode pertumbuhan dan perkembangan yang semakin pesat.

Kemudian, Revitalisasi birokrasi SDM Aparatur yang dilakukan dengan transformasi birokrasi ke arah e-governance melalui pengembangan inovasi, membangun kolaborasi dan sinergi serta dengan memberikan respons atas terjadinya perubahan lingkungan yang sangat cepat dan perkembangan era teknologi (Rahadian, 2019). Dengan terwujudnya birokrasi society 5.0 melalui tata kelola perencanaan pengembangan SDM Aparatur yang berbasis kompetensi maka diharapkan adanya perbaikan dalam hal sejauh mana aparatur pemerintah bebas dari korupsi, kolusi, dan nepotisme. Pasalnya, tindakan korupsi telah mengakibatkan pelanggaran hak ekonomi dan sosial masyarakat yang dapat menimbulkan masalah sosial, ekonomi, dan kesejahteraan (Azhary, 2019). Birokrasi society 5.0 akan mendorong produksi layanan publik berkualitas tinggi untuk kebutuhan negara yang sedang berjuang melawan dinamika global yang lebih ketat. Selain itu, kapasitas dan tanggung jawab birokrasi untuk keberhasilannya akan meningkat, dan pola pikir serta budaya yang mewakili integritas dan kinerja akan semakin meningkat di masa depan. Hal ini sebagaimana disajikan pada Gambar 4. 


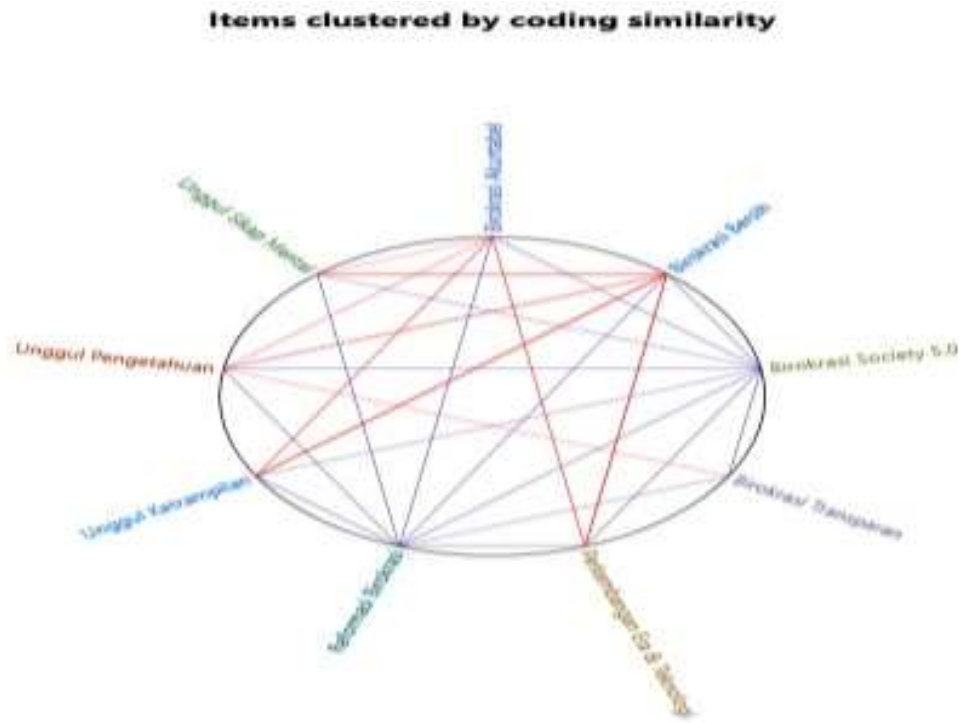

Gambar 4. Pengembangan SDM Aparatur Menuju Birokrasi Society 5.0 (Sumber: Hasil Pearson Correlations Cluster Analyses NVivo12 Plus, 2021).

Berdasarkan Gambar 4 terlihat bahwa adanya perkembangan era dan teknologi akan mendorong pemerintah untuk menjadikan birokrasi bersih dan akuntabel sehingga akan berdampak pada terwujudnya aparatur pemerintah yang unggul ketrampilan, unggul sikap mental dan unggul pengetahuan. Untuk meningkatkan birokrasi yang bersih dan akuntabel, maka setiap SDM Aparatur harus memiliki keterampilan dan pengetahuan yang unggul dalam menggunakan teknologi sehingga kinerja birokrasi dapat berjalan optimal serta hasilnya dapat dipertanggungjawabkan kepada publik. Hal ini sebagai upaya penting untuk menjaga kepercayaan masyarakat terhadap birokrasi itu sendiri pada masa mendatang. Sehingga, dalam melakukan tata kelola perencanaan pengembangan SDM Aparatur untuk menjadi birokrasi society 5.0 perlu dilakukan dengan melalui upaya reformasi birokrasi yang bersih, transparan dan akuntabel secara berkelanjutan. Oleh karena itu, upaya reformasi birokrasi dapat dilakukan melalui perencanaan pengembangan SDM Aparatur dengan transformasi menuju e-governance melalui inovasi, kolaborasi, membangun sinergi serta menjadikan birokrasi responsif terhadap perubahan era dan perkembangan teknologi secara cepat dimasa depan (Rahadian, 2019).

Kemudian, Birokrasi society 5.0 berupaya untuk menjadikan pembangunan aparatur negara yang berkesinambungan terhadap perkembangan teknologi dan perubahan sosial masyarakat sehingga akan menjadikan SDM Aparatur yang berdaya saing dalam mewujudkan tujuan pembangunan nasional. Dengan keterpaduan pemanfaatan teknologi di dalam birokrasi pemerintahan maka akan menciptakan SDM Aparatur dengan sistem kinerja yang terintegrasi antara birokrasi di level pusat dan diaras lokal. Penggunaan sistem pemerintahan berbasis elektronik untuk mengefisienkan birokrasi dapat menjadi inisiatif strategis untuk mewujudkan pemerintahan yang efektif, andal, dan transparan (Yuhefizar et al., 2019). Hal ini akan menghasilkan birokrasi pemerintahan yang kuat dan akan mendorong terlaksananya kebijakan dan program pembangunan nasional yang terintegrasi dengan mempertimbangkan keterkaitan antara faktor ekonomi, sosial, dan lingkungan. Pengembangan SDM Aparatur yang berorientasi terhadap keunggulan kompetensi pengetahuan dan keterampilan akan dapat mengelola ICT yang terintegrasi dengan aman dan andal. Sedangkan pengembangan aparatur pemerintah yang unggul sikap mental dapat mengelola pelayanan dengan inovatif, adaptif dan responsif melalui sikap humanis terhadap segala bentuk perubahan dan keinginan kebutuhan masyarakat. Tata kelola pengembangan SDM diperlukan dengan meningkatkan kompetensi aparatur negara terhadap 
pemanfaatan ICT sehingga dapat berkontribusi secara optimal untuk mewujudkan good governance (Faruqi, 2019; Mardawani \& Relita, 2019; Rustandi, 2019).

\section{Menuju Birokrasi Society 5.0}

Perkembangan era dan teknologi yang semakin cepat telah mendorong birokrasi untuk melakukan perubahan melalui tata kelola pengembangan SDM Aparatur. Sumber daya manusia sebagai penggerak dan dinamika pemerintahan berada pada garda terdepan dalam melakukan perubahan dalam mewujudkan aparatur negara yang kompeten, yaitu aparatur SDM yang memiliki keahlian dan keterampilan manajerial yang unggul, guna mempercepat pembangunan tata pemerintahan yang baik. Karena dinamika perubahan lingkungan yang semakin membutuhkan kemampuan analitis untuk menghasilkan informasi, maka penting dilakukan pengembangan SDM birokrasi pemerintahan dengan meningkatkan keterampilan belajar yang berkelanjutan (Gunastri, 2013). Dalam rangka meningkatkan proses pembangunan berkelanjutan, motivasi bagi pegawai untuk terus belajar dan menambah pengetahuannya tentang pekerjaan di unit lainnya akan membuat seorang pegawai tidak hanya menguasai satu bidang saja, akan tetapi dapat menguasai dan tahu bagaimana melaksanakan pekerjaan di semua bidang. Diperkuat dengan keterampilan ICT, literasi pengetahuan dan literasi media, serta pemahaman tentang data besar dan kecerdasan buatan (Arief \& Saputra, 2019).

Dewasa kini, Pemerintah sudah mestinya harus fokus pada pengembangan SDM Aparatur yang memiliki pengetahuan dan kemampuan teknis yang signifikan dan relevan secara substansial dan kontekstual dengan perkembangan zaman. Pengetahuan substansial yakni penguasaan pengetahuan yang meliputi kemampuan kognitif dan analitik. Sedangkan pengetahuan kontekstual yakni kemampuan SDM dalam memahami kondisi lingkungan organisasi baik lingkungan alam, sosial, budaya, dan iklim kerja. Tidak hanya itu, Birokrasi juga harus mampu mengadopsi teknologi dan memiliki pengetahuan terkait big data yang terintegrasi ke semua unit yang ada di birokrasi. Sehingga diperlukan internalisasi budaya akademis ke dalam birokrasi agar SDM Aparatur memiliki mental pembelajar dan termotivasi meningkatkan pengetahuan serta kemampuannya dalam memanfaatkan teknologi. Selain itu SDM Aparatur di masa depan harus memiliki keterampilan mental, keterampilan sosial, dan keterampilan manual. Keterampilan mental, yaitu penguasaan atas keahlian seseorang dalam menghadapi fenomena dan kejadian yang muncul di sekitar dunia, serta kemampuan untuk melakukan kajian yang akurat terhadap peristiwa yang terjadi. Keterampilan sosial, yaitu kemampuan untuk bergaul dengan orang lain dan bisa saling berkolaborasi. Sementara itu, keterampilan manual mengacu pada kemampuan seseorang untuk menggunakan anggota tubuh dan indranya untuk menghasilkan barang dan jasa kreatif yang bernilai tinggi dan berorientasi pada inovasi. Pada prosesnya, Inovasi diperlukan untuk adaptasi terhadap perubahan dan pengembangan SDM aparatur pemerintah agar mampu menciptakan inovasi pelayanan publik yang berorientasi terhadap pemanfaatan teknologi informasi (Wardani, 2019). Dengan demikian, keterampilan dan kemampuan spesifik aparatur pemerintah dapat menjadi landasan bagi pengembangan pola pikir profesional seperti yang ditunjukkan oleh kapabilitasnya dalam mengidentifikasi kebutuhan masyarakat, menetapkan tujuan, dan memprioritaskan program berdasarkan kebutuhan dan harapan masyarakat. Alhasil, birokrasi akan lebih mampu merespons setiap persoalan yang muncul, menunjukkan fleksibilitas dalam segala keadaan, dan menjaga kepercayaan publik. Sehingga, Adanya komitmen dan kesadaran diri sangat dibutuhkan oleh setiap aparatur pemerintah untuk membangun budaya birokrasi agar tidak kehilangan kepercayaan publik (Rivai, 2019).

Birokrasi society 5.0 selain memiliki keunggulan pengetahuan dan keterampilan dalam memanfaatkan teknologi juga harus unggul dalam sikap mental. Profesionalisme SDM aparatur tidak hanya sebatas keahlian dalam berteknologi dan pengetahuan tinggi, tetapi harus diimbangi dengan perilaku yang beretika moral. Hal ini karena SDM aparatur bukan hanya bekerja untuk 
kepentingan individu, tetapi juga untuk kepentingan masyarakat. Dibutuhkan perubahan budaya birokrasi yang responsif dan aspiratif dalam merespons setiap bentuk tuntutan publik sehingga SDM Aparatur perlu melakukan internalisasi nilai-nilai tersebut ke dalam sikap mental perilaku aparatur birokrasi yang memberikan pelayanan kepada masyarakat. Perubahan pola pikir dan sikap mental SDM terhadap modernitas dalam birokrasi society 5.0, ke depannya harus mampu menghasilkan birokrasi dengan budaya kerja yang berkelanjutan, efektif, manusiawi, disiplin, dan kompeten (Sihite, 2018). Hal ini menjadi dasar dari upaya mengintegrasikan tata kelola sumber daya manusia ke dalam tata kelola yang dinamis berdasarkan prinsip pemikiran antisipatif, reflektif, dan kreatif yang menguntungkan organisasi pemerintah. Sehingga mereka tidak hanya memiliki posisi yang baik secara kelembagaan untuk menangani isu-isu publik, tetapi juga memiliki modal mental untuk menghadapi potensi tantangan dan meningkatkan kepercayaan publik.

Secara fundamental, birokrasi society 5.0 akan berperan menjadi birokrasi dengan berlandaskan karakteristik yang lebih peduli terhadap masyarakat. Setiap aparatur negara yang merupakan seorang birokrat sebagai pelayan publik harus memahami dan memiliki kesadaran sikap yang tinggi, bahwa orientasi kerja adalah memenuhi kepentingan masyarakat secara maksimal. Aparatur birokrasi pada era society 5.0 harus memiliki kapasitas pribadi berupa etika profesi dan moralitas yang berlandaskan nilai-nilai kehidupan sosial yang berakar pada sistem nilai yang hidup dalam masyarakat, bukan menjadi alat kecerdasan buatan dari teknologi atau sebaliknya memperalat teknologi untuk mengambil keuntungan pribadi secara ilegal. Birokrasi dalam era society 5.0 menjadi penting untuk diwujudkan melalui pengembangan pengetahuan yang didukung teknologi dan kualitas sumber daya aparatur sehingga dapat berkontribusi terhadap dalam berbagai sektor publik (Faruqi, 2019). Pengaruh Pengembangan SDM Aparatur Menuju Birokrasi di Era Society 5.0 dapat dilihat pada Tabel 1.

Tabel 1. Pengaruh Pengembangan SDM Aparatur Menuju Birokrasi di Era Society 5.0

\begin{tabular}{ccc}
\hline Code A & Code B & Person Correlation Coefficient \\
\hline Unggul Keterampilan & $\begin{array}{c}\text { Perkembangan Era \& } \\
\text { Teknologi } \\
\text { Unggul Sikap Mental }\end{array}$ & $\begin{array}{c}\text { Perkembangan Era \& } \\
\text { Teknologi }\end{array}$ \\
Unggul Sikap Mental & $\begin{array}{c}\text { Birokrasi Transparan } \\
\text { Birokrasi Transparan }\end{array}$ & 0,160357 \\
Unggul Keterampilan & $\begin{array}{c}\text { Perkembangan Era \& } \\
\text { Teknologi }\end{array}$ & 0,1 \\
Unggul Pengetahuan & 0,069007 \\
Nilai Person Correlation Coefficient $>0,05$ Berpengaruh; <0,05 Tidak Berpengaruh
\end{tabular}

Sumber: Hasil Coding Cluster Analyses NVivo12 Plus, 2021

Berdasarkan Tabel 1 di atas menunjukkan bahwa terjadinya perkembangan era dan teknologi secara umum akan berpengaruh terhadap pengembangan SDM Aparatur menjadi SDM yang unggul keterampilan dan unggul sikap mental. Secara fundamental, Perkembangan era dan teknologi akan mendorong SDM Aparatur untuk memiliki keunggulan keterampilan dalam memanfaatkan kecanggihan teknologi dalam menghasilkan kinerja birokrasi yang tinggi dengan tetap menghadirkan sikap humanisme dalam memberikan pelayanan kepada masyarakat serta menyelesaikan persoalan publik (Faruqi, 2019). Kemudian, Pengembangan SDM Aparatur yang unggul keterampilan dan unggul sikap mental juga dipengaruhi dengan adanya birokrasi yang transparan. Sedangkan, Birokrasi yang transparan akan berdampak pada pengembangan kompetensi SDM Aparatur pemerintah dalam menciptakan aparatur birokrasi yang memiliki keahlian dengan didukung sikap mental yang melayani serta bersih dari tindakan korupsi yang dapat menjadi ancaman serius bagi negara dalam mewujudkan kesejahteraan masyarakat 
(Azhary, 2019). Namun, perkembangan era dan teknologi tidak akan serta merta dapat menghasilkan SDM Aparatur yang unggul pengetahuan, di mana dalam kontes ini inovasi diperlukan sebagai upaya untuk adaptasi terhadap terjadinya perubahan era dan tata kelola pengembangan SDM aparatur yang berorientasi terhadap pemanfaatan teknologi (Wardani, 2019).

\section{Kesimpulan}

Berdasarkan hasil dan pembahasan di atas dapat diketahui bahwa penguatan reformasi birokrasi dalam penciptaan SDM aparatur menuju era society 5.0 di Indonesia telah dilakukan oleh KemenPANRB melalui sistem merit yang membandingkan keterampilan dan kompetensi suatu jabatan pada tahap rekrutmen, pengangkatan, dan promosi, dengan tetap mempertimbangkan aspek integritas dan moralitas. Namun, penguatan reformasi birokrasi menuju era society 5.0 di Indonesia mengalami berbagai hambatan terkait masih dominannya patologi birokrasi, budaya korupsi, serta ketidaksiapan birokrasi akan pemanfaatan teknologi dan informasi dalam orientasi pelayanan publik kepada masyarakat. Oleh karena itu, Perencanaan pengembangan SDM Aparatur oleh KemenPANRB dalam memperkuat reformasi birokrasi menuju era Society 5.0 harus dilakukan secara tepat dengan merespons berbagai hambatan yang terjadi serta segala bentuk perubahan lingkungan dan perkembangan zaman.

\section{Daftar Pustaka}

Adlin, T. H. (2019). Penguatan Perilaku Anti Korupsi di Lingkungan Birokrasi Pemerintah Provinsi Riau. Nakhoda: Jurnal Ilmu Pemerintahan, 17(29), 46-55. https://doi.org/10.35967/jipn.v17i29.7058

Alekseev-Apraksin, A., \& Bertova, A. (2021). Leader 'S Strategy in Super Smart Digital Society. Proceedings of the 1st International Scientific Conference "Legal Regulation of the Digital Economy and Digital Relations: Problems and Prospects of Development" (Larder 2020), $171,207-214$.

Annisah. (2017). Usulan Perencanaan Smart City: Smart Governance Pemerintah Daerah Kabupaten Mukomuko. Jurnal Masyarakat Telematika dan Informasi, 8(1), 59-80. https://doi.org/10.17933/mti.v8i1.103

Arief, N. N., \& Saputra, M. A. A. (2019). Kompetensi Baru Public Relations Pada Era Artificial Intelligence. Jurnal Sistem Cerdas, 2(1), 1-12. https://doi.org/10.37396/jsc.v2i1.19

Azhary, V. H. (2019). Nepotisme dan Gratifikasi Sebagai Unsur Budaya Pada Korupsi Politik dan Birokrasi di Indonesia. Simposium Nasional Ilmiah Dengan Tema: (Peningkatan Kualitas Publikasi Ilmiah Melalui Hasil Riset Dan Pengabdian Kepada Masyarakat), 754762. https://doi.org/10.30998/simponi.v0i0.437

Bandur, A. (2019). Penelitian Kualitatif, Studi Multi-Disiplin Keilmuan Dengan Nvivo 12 Plus. Jakarta: Mitra Wacana Media.

Baskoro Wicaksono, Nur Laila Meilani, R. F. (2019). Perencanaan Pembangunan Kabupaten Bengkalis Aspek Kebudayaan Melayu Dalam Menopang Visi Provinsi Riau 2020. Nakhoda: Jurnal Ilmu Pemerintahan, 17(29), 22-34. https://doi.org/https://doi.org/10.35967/jipn.v17i29.7056

Dodi Faedlulloh, Yulianto, V. K. (2020). A Structural And Mindset Bureaucratic Reform Agenda For Jokowi's Second Term. Bisnis \& Birokrasi: Jurnal Ilmu Administrasi dan Organisasi, 27(2), 67-77. Https://Doi.Org/10.20476/Jbb.V27i2.11466

Dzakiyati, F. (2018). Modifikasi Perilaku Aparatur Ala Skinner: Suatu Model Pengembangan Sumber Daya Manusia Menuju Profesionalisme Birokrasi. Jurnal Ilmiah Tata Sejuta STIA Mataram, 4(1), 13-26. https://doi.org/10.32666/tatasejuta.v4i1.29

Fajar Rahmanto, Ulung Pribadi, A. P. (2021). Big Data: What Are The Implications For Public Sector Policy In Society 5.0 Era? Iop Conference Series: Earth And Environmental Science 
717, 1-7. https://doi.org/10.1088/1755-1315/717/1/012009

Fajriah, U. R., \& Razak, M. R. R. (2020). Pengaruh Perilaku Birokrasi Terhadap Pelayanan Publik Di Desa Timoreng Panua Kecamatan Panca Rijang Kabupaten Sidenreng Rappang. Jurnal Praja, 8(1), 48-56.

Farida, A. (2019). Studi Pustaka Tentang Perkembangan Teknologi dan Peningkatan Kepatuhan Pajak: Apakah Berbanding Lurus? Moneter - Jurnal Akuntansi Dan Keuangan, 6(2), 135140. https://doi.org/10.31294/moneter.v6i2.6183

Faruqi, U. Al. (2019). Future Service In Industry 5.0. Jurnal Sistem Cerdas, 2(1), 67-79. https://doi.org/10.37396/jsc.v2i1.21

Ferizaldi. (2018). Patologi Birokrasi Dalam Transformasi Politik Lokal: Tinjauan Terhadap Fenomena "Pajak Nanggroe" Di Aceh. Nakhoda: Jurnal Ilmu Pemerintahan, 16(27), 32 39. https://doi.org/https://doi.org/10.35967/jipn.v16i27.5793

Ferizaldi. (2019). Model Akuntabilitas Birokrasi di Era Otonomi Khusus Aceh (Tinjauan Terhadap Tes Shalat dan Baca Al-Qur'an di Kabupaten Aceh Barat Daya). Nakhoda: Jurnal Ilmu Pemerintahan, 17(29), 14-21. https://doi.org/10.35967/jipn.v17i29.7055

Fujii, T., Guo, T., \& Kamoshida, A. (2018). A Consideration Of Service Strategy Of Japanese Electric Manufacturers to Realize Super Smart Society (Society 5.0) (Vol. 2). Springer International Publishing. https://doi.org/10.1007/978-3-319-95204-8

Fukuyama, M. (2018). Society 5.0: Aiming For A New Human-Centered Society. Japan Spotlight, 2(August), 47-50. https://www/jef.or.jp/journal/

Gumilang, G. S. (2016). Metode Penelitian Kualitatif Dalam Bidang Bimbingan dan Konseling. Jurnal Fokus Konseling, 2(2), 144-159.

Gunastri, N. M. (2013). Pengembangan Sumber Daya Manusia Berbasis Kompetensi. Forum Manajemen, 11(2), 77-86.

Hadi, K. (2016). Korupsi Birokrasi Pelayanan Publik di Era Otonomi Daerah. Jurnal Penelitian Politik, 51-70.

Haning, M. T. (2018). Reformasi Birokrasi di Indonesia: Tinjauan Dari Perspektif Administrasi Publik. Jurnal Analisis Kebijakan dan Pelayanan Publik, 4(1), 25-37.

Hartanto, D. (2019). Kajian Wilayah Birokrasi Bersih dan Melayani Kepolisian Resort Kota Medan. Publikauma: Jurnal Ilmu Adminstrasi Publik, 7(2), 71-87. http://dx.doi.org/10.31289/publika.v7i2.2805

Hasan, N. (2012). Corak Budaya Birokrasi Pada Masa Kerajaan, Kolonial Belanda Hingga di Era Desentralisasi Dalam Pelayanan Publik. Jurnal Hukum, 28(2), 1073-1087.

Henriyani, E. (2019). Menumbuhkan Budaya Birokrasi Yang Inovatif dan Berdaya Saing Global. Dinamika: Jurnal Ilmiah Ilmu Administrasi Negara, 6(2), 6-10. http://dx.doi.org/10.25157/dinamika.v6i2.2255

Hidayat, E. S. (2019). Kinerja Pelayanan Birokrasi Dalam Mewujudkan Kepuasan Pelanggan. Dinamika: Jurnal Ilmiah Ilmu Administrasi Negara, 6(2), 43-49. http://dx.doi.org/10.25157/dinamika.v6i2.2260

Islah, K. (2018). Peluang dan Tantangan Pemanfaatan Teknologi Big Data Untuk Mengintegrasikan Pelayanan Publik Pemerintah. Jurnal Reformasi Administrasi, 5(1), 130 138.

Kumorotomo, W. (2019). Envisioning Agile Government: Learning From the Japanese Concept of Society 5.0 and the Challenge of Public Administration in Developing Countries. Advances In Economics, Bussines And Management Research: Annual Conference of Indonesian Association For Public Administration (IAPA 2019), 122, 144-163.

Kurniati, P. N., \& Nugroho, B. Y. (2019). The Urgency Of The Implementation Of The Cashless Government System In Building A Transparent And Accountable Bureaucracy. Jurnal Administrasi Publik, 9(2), 136-150. http://dx.doi.org/10.31289/jap.v9i2.2655

Maizunati, N. A. (2018). Implementasi Data Sektoral Terbuka Dalam Mendukung Smart 
Governance Di Kota Magelang. Journal of Public Administration and Local Governance, 2(2), 31. https://doi.org/10.31002/jpalg.v2i2.1082

Mardawani, \& Relita, D. T. (2019). Strategi Pemerintah Daerah Kabupaten Sintang Dalam Mewujudkan Visi Pemerintahan dan Good Governance. Jurnal Ilmiah Pendidikan Pancasila dan Kewarganegaraan, 4(1), 109-116.

Nashihuddin, W., \& Suryono, F. (2018). Tinjauan Terhadap Kesiapan Pustakawan Dalam Menghadapi Disrupsi Profesi di Era Library 4.0: Sebuah Literatur Review. Khizanah AlHikmah: Jurnal Ilmu Perpustakaan, Informasi, dan Kearsipan, 6(2), 86. https://doi.org/10.24252/kah.v6i2a1

Nasution, D. A. D., Nasution, A. P., \& Alpi, M. F. (2019). Pengaruh Penerapan Smart Asn Terhadap Pengelolaan Keuangan Negara Di Era Disrupsi Teknologi Indonesia 4.0. Seminar Nasional Sains \& Teknologi Informasi, 43-51.

Parjaman, T., Soedarmo, U. R., \& Enas. (2019). Penguatan Kapasitas Aparatur Untuk Meningkatkan Daya Saing Daerah di Era Global. Journal of Management Review, 1, 29-42. https://doi.org/http://dx.doi.org/10.25157/mr.v3i3.2869

Patrik Aspers, U. C. (2019). What Is Qualitative In Qualitative Research. Qualitative Sosiology, 42(2), 139-160. https://doi.org/https://doi.org/10.1007/s11133-019-9413-7

Purwaningsih, A. S., Afifuddin, \& Abidin, A. Z. (2019). Reformasi Birokrasi Pelayanan Publik Dalam Meningkatkan Kualitas Pelayanan Publik Studi Kasus Pada Pelayanan Kartu Keluarga di Dinas Kependudukan dan Pencatatan Sipil Kabupaten Malang. Jurnal Respon Publik Volume, 13(4), 82-86.

Rahadian, A. . (2019). Revitalisasi Birokrasi Melalui Transformasi Birokrasi Menuju EGovernance Pada Era Revolusi Industri 4.0. Prosiding Seminar Stiami, 6(1), 85-94.

Rivai, F. H. (2019). Bureaucracy Culture Enforcement to Encounter Industrial Revolution 4.0. Jurnal Transformasi Administrasi, 9(2), 128-138.

Rustandi. (2019). Kinerja Manajemen Sumber Daya Manusia di Era Disrupsi. Kebijakan: Jurnal Ilmu Administrasi, 10(2), 67-73.

Saksono, H., \& Manoby, W. M. (2021). Good Public Governance Towards Society 5.0 In Indonesia: A Review. Psychology And Education, 58(2), 4499-4511.

Sakti, B. (2019). Kompetensi Aparatur Pemerintah Daerah Dalam Sumber Daya Manusia di Era Reformasi. Pareto: Jurnal Ekonomi dan Kebijakan Publik, 2(1), 35-44.

Salgues, B. (2018). Society 5.0 Industry of the Future, Technologies, Methods and Tools. London: ISTE Ltd.

Saluky. (2018). Tinjauan Artificial Intelligence Untuk Smart Government. Itej (Information Technology Engineering Journals), 03(01), 1-9.

Setiawan, A., \& Fauzi, E. A. (2019). Etika Kepemimpinan Politik Dalam Penyelenggaraan Pemerintahan Indonesia. JPK: Jurnal Pemerintahan dan Kebijakan, 1(1), 1-12.

Sihite, M. (2018). Peran Kompetensi Dalam Mewujudkan Sumber Daya Manusia Yang Berdaya Saing Tinggi di Era Revolusi Industri 4.0: Suatu Tinjauan Konseptual. Jurnal Ilmiah Methonomi Volume, 4(2), 145-159.

Sirih, S. H., Ismail, I., \& Juharni. (2019). Development Strategies Of Human Resources In Bkpsdm Majene District. Jurnal Paradigma, 1(2), 1-6.

Soekarsono, R. (2019). Merubah Mindset ASN Menjadi Disruptive Mindset Sebagai Faktor Penentu Suksesnya Implementasi Industri 4.0 di Indonesia. Prosiding Seminar STIAMI, 6(1), 67-84.

Sudrajat, T. (2014). Eksistensi Kebijakan Pengisian Jabatan Struktural Dalam Kerangka Pengembangan Sdm Aparatur Berbasis Merit. Jurnal Kebijakan dan Manajemen PNS, 8(1), 61-72.

Sugiono, S. (2020). Digital Content Industry In Society 5.0 Perspective. Jurnal IPTEK-KOM (Jurnal Ilmu Pengetahuan dan Teknologi Komunikasi), 22(2), 175-191. 
http://dx.doi.org/10.33164/iptekkom.22.2.2020.175-191

Suwardana, H. (2018). Revolusi Industri 4. 0 Berbasis Revolusi Mental. Jati Unik: Jurnal Ilmiah Teknik Dan Manajemen Industri, 1(2), 102-110. https://doi.org/10.30737/jatiunik.v1i2.117

Umam, M. K. (2019). Dimensi Kepemimpinan Transformatif Era Disrupsi Perspektif Manajerial Birokrasi. Al-Wijdán: Journal of Islamic Education Studies, 4(2), 126-146. https://doi.org/10.1017/cbo9781107415324.004

Vasja Roblek, Maja Meško, Mirjana Pejic Bach, Oshane Thorpe, P. Š. (2020). The Interaction Between Internet, Sustainable Development, and Emergence of Society 5.0. Journal Data, 5(80), 1-27. https://doi.org/doi:10.3390/data5030080

Wardani, A. K. (2019). Urgensi Inovasi Pelayanan Bidang Administrasi Publik di Era Disrupsi. Dinamika: Jurnal Ilmiah Ilmu Administrasi Negara, 6(2), 30-35.

Wasitarini, D. E. (2019). Perpustakaan Satu Data. Jurnal Madika, 5(2), 26-39.

Yudoprakoso, P. W. (2019). Kecerdasan Buatan (Artificial Intelligence) Sebagai Alat Bantu Proses Penyusunan Undang-Undang Dalam Upaya Menghadapi Revolusi Industri 4.0 di Indonesia. Simposium Hukum Indonesia, 1(1), 450-461.

Yuhefizar, Sanjani, H., \& Chadri, R. (2019). Penerapan Sistem Pemerintahan Berbasis Elektronik (E-Government) Dengan Pendekatan Bottom-Up Berbasis Web di Sumatera Barat. Prosiding Seminar Nasional Multidisiplin Ilmu, 2(1), 303-309.

Zaenuri, M. (2015). Manajemen SDM di Pemerintahan. Yogyakarta: LP3M Universitas Muhammadiyah Yogyakarta. 